\title{
Post-Mining Areas: Analysis of Women's Involvement in the Informal Sector
}

\author{
Ade Muana Husniati ${ }^{1, *}$, Maryam Maryam ${ }^{1}$, Zulham Zulham ${ }^{1}$ \\ ${ }^{1}$ Universitas Malikussaleh, Aceh - Indonesia
}

\begin{abstract}
Lhokseumawe and Aceh Utara areas have been the largest natural gas producing areas in Aceh for 30 years since 1971. Lhokseumawe has also earned the nickname as a city of petro dollars even to this day despite the splendor of the city has dimmed in line with the end of gas exports in October 2014. Central Bureau of Statistics (BPS) data shows that until March 2016 the number of poor people in Lhokseumawe City was $11.98 \%$. While Aceh province itself in March 2017 became the poorest province in Sumatra. Given the limitations of natural resources, it is fitting for economic development that does not depend on general allocation funds (DAU) and Special Allocation Fund (DAK) sourced from the central government. Local governments should be able to develop the leading sectors in Lhokseumawe such as services, trade, tourism and marine sectors. Which plays an important role in this city is the trade and marine sector. One of the informal Sectors that will be of concern in this research is the service and trade sector involving women as traders in traditional markets. Women became important in this study because of its contribution in this region so visible.
\end{abstract}

Keywords: Informal Sector, Women, Post Mining Area

\section{Introduction}

Lhokseumawe and Aceh Utara are one of the largest natural gas producing areas in Indonesia starting in 1971, Lhokseumawe is often referred to as the petrodollar city when natural gas exploration is active. Even to this day the name is still often heard even though the golden age of the gas industry has been lost without trace. The splendor of the city began to fade with the end of gas exports in October 2014. Lhokseumawe city slogan "Bandar Silaturahmi" [1] is not popular among the people of Lhokseumawe city itself. This shows the use of the tagline is not maximal and has not become a standing identity. It could be that tagline is not interesting. It takes the government seriousness in building the identity of the city to be a breakthrough in facilitating changes that occur due to competition between cities in the future. The identity of the city will later become an integrated part with the image of the city that is part of the city communications. And of course building the identity of the city should be accompanied by the development of its people in various sectors, including the informal sector.

\section{Methodology}

To support the development of the region after the end of Arun gas, the city needs a variety of structuring of the economy after the end of mining glory. Along with the various dynamics of post-depleting crops, the paper industry and fertilizer that has ever triumphed also must stop operating. Thus, factories and other infrastructure that has been built into useless and futile. Which still operates only state-owned fertilizer companies. The bright spot re-emerged along with the enactment of Government Regulation (PP) no. 5 years 2017 on Special Economic Zones (KEK) Arun Lhokseumawe on January 17,2017 . That is, the economy is expected to be able to become an engine of the economy and bring in investors. But of course after the signing of PP KEK Arun Lhokseumawe by President Jokowi, the people's

\footnotetext{
* Corresponding author e-mail ademuana@gmail.com
} 
economy does not suddenly change to be good. It still takes a long process for it.

One of the informal sectors to which we are concerned is trading in traditional markets in this city. Especially women traders who work to help the economy of the middle to lower class families. This is interesting considering the number of male and female traders in the five traditional markets in this city seem comparable and the women in this sector are clearly visible.

The mining area is an area located in a mineable zone and within it there is a distribution of excavated mineral materials [2]. Exploitation of natural resources of mining is generally only directed to achieve high economic growth without regard to proportional environmental sustainability and improving the quality of social life of local communities. This is what happened during the thirty years of operation of several mining industries in Lhokseumawe and North Aceh which are now moving into post-mining areas after the mineral resources for energy is slowly thinned out.

The management of the mining area through the concept of local self-reliance puts the community and its environment as the main actors of development in the region with the foundation of social and cultural wisdom that is owned so as to realize the process of sustainable development. The benefits of development should be enjoyed by most of the community and reduce the inequality of the seeds of social conflicts and threats, including by accommodating community empowerment.

In addition to the cultural issues and stereotypes developed in the community there are some reasons that make the involvement of women in the formal sector low. The Minister of Finance stated that in the formal sector the involvement of women is only 32 percent, while the informal sector involvement reaches 55 percent. This is one of the reasons why the informal sector is one of concern in our research. According to Mulyadi S (2003: 95) [3], informal sector is the business units that do not get official economic protection by the government.

\section{Discussion}

The city of Lhokseumawe located in Aceh Province before separated in 2001 was part of North Aceh Regency. The administrative city of 181.06 KM2 consists of four districts namely Blang Mangat, Banda Sakti, Muara Satu and Muara Dua with a population of 187,455 people (BPS Data 2014). With the end of the mining sector, there will be a reduction in the velocity of money and the weakening of public purchasing power and the decreasing of employment. To utilize the existing industrial facilities in order not to become obsolete and useful, the government in early 2017 set Lhokseumawe and North Aceh to be one of the Special Economic Zone (KEK) of 3000 hectares in former PT. Arun, PT. KKA, PT. PIM, PT. AAF, PT Pelindo I as an oil, gas, energy, petrochemical industry, food support, logistics, and cement bag manufacturing industries.

But to re-live the economy of society through KEEK would take time. Community economic development through the informal sector is often ignored. Yet through this sector, people are able to sustain their lives. In this sector also the involvement of women look real. People with low education level and come from village dare to try their luck and seek fortune in this sector. Thus, it should be that the informal sector of trade in traditional markets has received serious attention from the government. The informants in this study were women traders in traditional markets and female parking attendants in five traditional markets in the city of Lhokseumawe. their education level is quite varied. Some do not finish their elementary school but some even have completed college education, though rare are found. The following informants in this study:

Table 1: Informan

\begin{tabular}{|c|c|c|c|c|}
\hline $\begin{array}{c}\mathrm{Nu} \\
\mathrm{mbe} \\
\mathrm{r}\end{array}$ & Name & Age & Work & $\begin{array}{c}\text { Market } \\
\text { Location }\end{array}$ \\
\hline 1 & $\begin{array}{c}\text { Siti } \\
\text { Aisyah }\end{array}$ & 48 & $\begin{array}{l}\text { Bumbu } \\
\text { Traders }\end{array}$ & Peuntet \\
\hline 2 & Henni & 36 & $\begin{array}{l}\text { Vegetable } \\
\text { seller }\end{array}$ & Peuntet \\
\hline 3 & $\begin{array}{c}\text { Hasna } \\
\text { Matsyah }\end{array}$ & 55 & $\begin{array}{l}\text { Bumbu } \\
\text { Traders }\end{array}$ & Cunda \\
\hline 4 & Dahrul & 20 & $\begin{array}{c}\text { Vegetable } \\
\text { seller }\end{array}$ & Cunda \\
\hline 5 & Nilawati & 55 & $\begin{array}{l}\text { Vegetable } \\
\text { seller }\end{array}$ & Cunda \\
\hline 6 & Suryati & 38 & $\begin{array}{c}\text { Vegetable } \\
\text { seller }\end{array}$ & Impres \\
\hline 7 & Nurjannah & 38 & $\begin{array}{l}\text { Vegetable } \\
\text { seller }\end{array}$ & Impres \\
\hline 8 & Agustina & 50 & Fish seller & Impres \\
\hline 9 & Lia & 45 & Fish seller & Impres \\
\hline 10 & $\begin{array}{c}\text { Cut } \\
\text { Lailatul }\end{array}$ & 35 & $\begin{array}{c}\text { Parking } \\
\text { attendants }\end{array}$ & Impres \\
\hline 11 & $\begin{array}{l}\text { Mahda } \\
\text { Leina }\end{array}$ & 35 & $\begin{array}{l}\text { Vegetable } \\
\text { seller }\end{array}$ & Batuphat \\
\hline 12 & Mariana & 45 & $\begin{array}{l}\text { Cake and } \\
\text { tape seller }\end{array}$ & Batuphat \\
\hline
\end{tabular}




\begin{tabular}{|c|c|c|c|c|}
\hline 13 & Aminah & 44 & $\begin{array}{c}\text { Vegetable } \\
\text { seller }\end{array}$ & Kota \\
\hline 14 & Salma & 58 & $\begin{array}{c}\text { Vegetable } \\
\text { seller }\end{array}$ & Kota \\
\hline
\end{tabular}

The female traders who became informants of this research half of them is the head of the family (KK). There because it was divorced from her husband and then she must provide for his children but there are also because her husband had died. There is also a husband who has no a permanent job, then must be assisted by his wife by trading. But not infrequently through trading business in the traditional market they are able to make their children graduated from college. Earnings through trade are sufficient to finance daily needs and sufficient help the family economy. Choosing to be a trader in a traditional market is done because this is what they think can be done with sufficient capital although with little challenge. In addition, there is also kind of this business is a legacy of his family (mother and grandmother). This is as shown by a vegetable trader who is an educational scholar. She went on to trade in the traditional market as her grandmother had pioneered. She thinks trading in the traditional market is more profitable than being a teacher like her educational background. When she became a teacher, her salary was only 150,000 rupiah per month.

Daily income of small traders in traditional markets is quite varied. There is the smallest when no regular buyer can only 30.000-50.000 rupiah but there is also the smallest 1.000.000 rupiah and when crowded reach 2.000.000 rupiah, particularly like at the time before fasting (Ramzan), Eid celebration (Idul Fitri and Idul Adha) and other religious ceremony. All traders who become informants also pay a varied daily tax retribution with ranges from 2000 rupiah to 5000 rupiah per day. For those who do not have a place, they have to rent a stall per year to the previous owner of 360,000 2,500,000 rupiah.

According to traders, they do not get business assistance from the government. They only get an offer from the Bank. As performed by Mrs. Hasna who took the capital from Bank Mandiri then pay the installment every day for 20.000 rupiah. There are not many female traders who use loans from SPP (women's savings and loans by PNPM Mandiri (national community empowerment program). The reason according to one of the traders is that, for example, given a loan of 2,000,000 rupiah, it will be quoted from the merchant per week amounting to 50,000 rupiah. They are afraid there will be a time when they can not afford to pay the mortgage, while many women traders do not know the information related to the business capital loan.For the development of the informal sector The municipal government through the industry, trade and cooperatives (Disperindagkop) provide business assistance is limited to fishing business (fishermen).

There are cleaners in every market even though their work is not maximally done. One reason is that the garbage fleet has not fully reached the garbage service. Traders sometimes need to pick up the trash and throw it themselves. In fact, there is also fee to be paid of 2000 to 5000 rupiah per day in addition to cleaning service retribution. Traditional market conditions in this petrocity city are almost the same as traditional markets in Aceh generally, muddy when it rains, including the Batuphat market directly closed to the housing complex of the LNG Company.

There is not much hope of the women traders in the traditional market of this petro dollar city. Keeping market alive, a clean market, neat and not muddy, conserved by the government, especially the clarity of the use of the place, and loan assistance business development, the government is also expected to provide a place for the small traders to complain, which is usually promised by legislative candidates during the campaign period.

\section{Conclusion}

Non-renewable natural resources are limited time. Continuous exploring without clear management will leave only old iron and social problems for the surrounding community. As experienced by the city of Lhokseumawe which is not visible progress in terms of clean, comfortable, order, neat arrangement of cities through planning, programs and policies to tackle various issues and problems that occur as a city that once became an industrial area. Looking at the informal sector of trade in traditional markets there is a balance of roles between men and women, of course this sector needs to get the attention of the authorities regarding policies that favour the traders and help raise their economies. Certainly not excessive attention by providing information services related to daily retribution, Rent a clear place, as well as business development assistance.

\section{References and Notes}

1. A.M. Husniati, and Maryam, "Konstruksi Identitas Pariwisata Kota Lhokseumawe (Langkah Awal Identifikasi Persoalan Pengembangan Industri Pariwisata di Aceh)", Prosiding ICCIC: Komunikasi Industri \& Komunitas. ISBN: 978602-74139-1-7, Fakultas Ilmu Komunikasi Taruma Negara, Jakarta(2016). 
2. R. Adisasmita, Pembangunan Kawasan dan Tata Ruang, (Graha Ilmu, Yogyakarta 2010).

3. S. Mulyadi, Ekonomi Sumber Daya Manusia dalam Perspektif Pembangunan ( PT Raja Grafindo Persada, Jakarta 2003).

4. A. Salim, Teori dan Paradigma Penelitian Sosial (Pemikiran Norman K. Denzin \& Egon Guba, dan Penerapannya) (PT Tiara Wacana, Yogyakarta, 2001).

5. Kumparan, "SriMulyani: Perempuan Lebih Banyak Bekerja di Sektor Informal”, 20 April (2017). 